\title{
Debat
}

\section{Hvornår bliver arbejdspladsens rum stuerene?}

Peter Holdt Christensen

Tlangt den størstedel af vores arbejdsdag befinder vi os i fysiske rum, mens vi i en lidt mindre del af arbejdsdagen er undervejs fra et rum til et andet. Det er således i rummene, at vi har vores mere eller mindre faste arbejdsplads, det er i rummene, at vi mere eller mindre tilfældigt mødes med kollegerne, og det er i rummene, at vi fx enten kan isolere os for at være kreative eller sammen med andre kan 'brainstorme' hen mod den næste nye idé.

Rum har stor indflydelse på vores arbejdsdag. Men inden for ledelsesdisciplinen er rum typisk udelukkende blevet overladt til arkitekter, hvilket der på mange måder er sund fornuft i. De har nemlig den faglige viden om bl.a. dimensionering og indretning af rum. De er dog ikke altid opmærksomme på, hvordan rum påvirker adfærd, hvilket kan føre til ubehagelig overraskelser, når det viser sig, at den nye bygning producerer stor utilfredshed med jobbet, eller at de nye lokaler ikke i tilstrækkelig grad understøtter samarbejde og videndeling.

For at arbejdspladsens rum kan blive stuerene - det vil sige, at de ligesom mange andre organisatoriske aktiviteter bliver betragtet som en strategisk vigtig ressource - er det nødvendigt med mere forskning inden for området. Rum har ikke haft le- delsesforskningens bevågenhed, og derfor er der i praksis kun få ledere, der arbejder - eller tør arbejde - med rum som en strategisk ressource. For det andet er der behov for et opgør med, at rum udelukkende er arkitekters værk. Den manglende interesse for rum som en strategisk ressource er måske snarere en berøringsangst med den disciplin, der traditionelt har haft monopol på rum. Men da rum handler om både arkitektur og adfærd, er det naturligvis vigtigt at være opmærksom på samspillet mellem netop arkitektur og adfærd. Det er lige præcis, hvad rum som en strategisk ressource handler om.

Når forskningen i koblingen mellem adfærd, arkitektur og ledelse i så mange år har befundet sig, og i dag fortsat befinder sig, i en slags dødvande, hvor der er enkelte forskningsindsatser på området, men hvor det generelle billede snarere er, at den strategiske anvendelse af rum er mindre krusninger på det store ocean af ledelsesteorier, skyldes det måske især den dårlige start, den systematiske forskning i rum fik for næsten 100 år siden og den alt for dominerende rolle, diskussionerne for og imod åbne kontorlandskaber i mange år har haft - og stadigvæk har.

Nogle af de bedst kendte og også mest 
skelsættende eksperimenter inden for ledelsesteorierne er Hawthorne-studierne, der fandt sted fra 1924 til 1932. Fabrikken Hawthorne Works var organiseret omkring en række samlebånd i flere større produktionshaller, og til at deltage i eksperimenterne udvalgte man 12 arbejdere, som blev isoleret $\mathrm{i}$ et forsøgslokale. Eksperimenterne havde som udgangspunkt til formål at identificere, hvilke belysningsforhold der resulterede i den bedste produktivitet. Således var eksperimenterne forankret i en form for arkitektonisk determinisme, hvor det blev antaget, at det især - og nærmest udelukkende - er rummet, der har indflydelse på individets adfærd og dermed ikke mindst individets produktivitet. Men forskerne kunne ikke entydigt fremhæve enkelte påvirkninger som de bedste, fordi arbejderne - uanset hvordan de blev påvirket - blev ved med at øge deres produktivitet. Selv da man fjernede alle påvirkninger, og arbejderne var organiseret som inden, de blev anbragt i forsøgslokalet, blev produktiviteten ved med at stige. En af mest udbredte konklusioner fra disse eksperimenter er, at bare det at være genstand for eksperimenter - eller for den sags skyld opmærksomhed - i sig selv medfører en øget effektivitet.

Derved understregede Hawthorne-studierne at ikke udelukkende rum, men også hvad der kan betegnes som menneskets indre rum, har en central betydning for opfattelsen af det gode arbejde, hvilket efterfølgende har haft stor indflydelse på især motivationsforskningen. Så selvom Hawthorne-studierne tog udgangspunkt i de fysiske rums indflydelse på arbejdet (og i første omgang i særdeleshed belysningen), førte resultaterne fra studierne i høj grad til, at de fysiske rums rolle i organisationen - og dermed generelt også i forskningen blev ignoreret. Al forskning og praksis inden for rum blev kastet over styr til fordel for et fokus på elementer inden for 'human relations'-skolen som fx medarbejderes sociale fællesskab og inddragelse i beslutninger. Mens mange ledelsesforskere således betragter Hawthorne-studierne som et gennembrud for den moderne ledelsesforskning, så gav studierne den hidtidige forskning inden for rum et foreløbigt dødsstød.

Forskningen i forholdet mellem mennesker og rum begynder først igen i løbet af 1940'erne og 1950'erne at markere sig som et selvstændigt forskningsfelt, der bygger på en række allerede etablerede forskningsdiscipliner - især psykologien og social-psykologien - og som altså nuancerer Hawthorne-studiernes fokus på udelukkende arkitektonisk determinisme. Men denne del af forskningen har kun ganske få koblinger til ledelsesforskningen.

En af de få koblinger, der dog er til ledelsesforskningen, startede i 1950'erne i en forstad til Hamburg, Quickborn, hvor de ansatte i konsulentvirksomheden The Quickborner Team mente, at der i kontorarbejdet var behov for langt mere kommunikation, og at organisationer - der oftere og oftere måtte forandre sig - også i deres fysiske rum havde behov for en langt højere grad af fleksibilitet. Dette førte til udviklingen af begrebet 'bürolandschaft' - som vi i dag også bedre kender som kontorlandskabet.

Kontorlandskabet er i dag formentlig det område inden for arbejdspladsens fysiske rum, der bliver flittigst debatteret, og dermed dukker der endnu et problem op for den mere strategiske brug af rum. Nemlig at rum ikke kun er en diskussion af enten kontorlandskaber eller ikke. Den strategiske brug af arbejdspladsens rum er langt mere nuanceret, men kompleksiteten - og ikke mindst mulighederne - i ledelse af rum bliver oftest udelukkende reduceret til en diskussion for og imod kontorlandskaber.

Når rum anvendes strategisk, betyder det, at de får bevågenhed, fordi de netop også påvirker menneskers adfærd og der- 
med er med til at påvirke bl.a. kreativitet, motivation, videndeling og samarbejde. Rum påvirker 'performance', men det kræver et langt større fokus på, hvad rum er, og hvad rum kan gøre. Det strategiske arbejde med rum består derfor for det første af en holdningsændring fra, at rum blot er noget, arkitekter arbejder med, til at rum er en del af den måde, organisationer fungerer på. For det andet er der behov for forventninger til rum: Rum gør noget, men hvad er det, de skal hjælpe med til at gøre i organisationen? For det tredje skal rum vurderes ud fra den måde, de fx indrettes og dimensioneres på, og så de forventninger, der er til rum. Endelig, for det fjerde, er det strategiske arbejde med rum ikke alene funderet $\mathrm{i}$ en praksis, der har forventninger til og vurderer rum. Det strategiske arbejde med rum er også baseret på forskningsbaseret viden om området - og selvom der efterhånden findes noget forskning om området, er der fortsat brug for meget mere forskning om, hvad, hvorfor og hvordan rum påvirker.

Rum påvirker både den måde, mennesker har det på, og den måde, mennesker interagerer med hinanden på. Men vi tænker ikke altid over, at rum påvirker. Rummene er der bare, og vi færdes bare i dem. Derfor er vi heller ikke altid dygtige nok til at udnytte de muligheder og gennemskue de udfordringer, rum indeholder. Rum giver dog organisationer nærmest uanede muligheder for at påvirke menneskers adfærd, men før rum bliver en strategisk ressource er der som nævnt ikke mindst brug for mere ledelsesforskning og dermed evidens. Der er også brug for et opgør med den noget ensidige forestilling om både arkitektonisk determinisme og rum som noget, der udelukkende handler om for eller imod kontorlandskaber. Rumforskning er langt mere nuanceret, og arbejdspladsens rum burde derfor i langt højere grad betragtes som strategisk stuerene.

Peter Holdt Christensen, lektor, ph.d., Department of Strategic Management and Globalization, Copenhagen Business School

e-mail: phc.smg@cbs.dk 